\title{
GESTÃO DE CUSTOS APLICADA À BOVINOCULTURA DE CORTE: O CASO DA FAZENDA PARAÍSO EM JUINA-MT
}

\section{COSTS MANAGEMENT APPLIED TO BEEF CATTLE: THE CASE OF PARAÍSO FARM AT JUINA-MT (BRAZIL)}

\author{
Rosangela Nunes da Silva de Souza ${ }^{1}$ \\ Laércio Juarez Melz
}

\begin{abstract}
Resumo
Este trabalho procurou, através do sistema contábil, utilizar as informações, como ferramenta aos gestores na propriedade rural, que desenvolva atividade de pecuária de corte. Procurou-se verificar se a empresa em estudo conhece o custo de produção. Buscou-se identificar as práticas contábeis, que implicam em comparar receitas e despesas, bem como organizar orçamentos. A ênfase foi para atividade de engorda, por meio de estudo de caso na Fazenda Paraíso, na cidade de Juína no Estado de Mato Grosso, no ano de 2008. Foi identificado que a empresa conhece o seu custo de produção. A receita bruta obtida foi suficiente para cobrir custos e despesas. Obtendo um retorno financeiro de 2,8\% ao mês.

Palavras-chaves: Contabilidade de Custos, Pecuária de Corte, Empresa Rural.
\end{abstract}

\begin{abstract}
This article sought, through the accounting system, using the information, as a tool for managers in the rural property to develop activity of beef cattle. We sought to determine whether the company under study know the cost of production. We tried to identify the accounting practices, which involve comparing income and expenditure as well as organize budgets. The emphasis was for the fattening activity through a case study in the city of Paradise Farm Juin in Mato Grosso in the year 2008. It was identified that the company knows the cost of production. The gross revenue obtained was sufficient to cover costs and expenses. Getting a financial return from $2.8 \%$ a month.
\end{abstract}

Keywords: Cost Accounting, Cutting Livestock, Rural Business.

\section{INTRODUÇÃO}

A pecuária de corte representa importante setor na economia brasileira e, que algumas informações que fogem a competência dos gestores têm comprometido o bom desempenho da atividade. De acordo com a Confederação da Agricultura e Pecuária do Brasil (CNA), em 2007 o PIB do agronegócio foi de US\$ 299 bilhões, sendo responsável por cerca de 24\% do PIB brasileiro. Desse total US\$ 86 bilhões vindos da pecuária representando 28,76\%. O Brasil exporta só em carne bovina, mais de US\$ 5 bilhões por ano, representa mais de 7\% do PIB

\footnotetext{
${ }^{1}$ Contadora formada pela Universidade do Estado de Mato Grosso (UNEMAT). E-mail:

${ }^{2}$ Doutorando em Administração (UFSM), Mestre em Engenharia de Produção (UFSCar), Professor de contabilidade na Universidade do Estado de Mato Grosso (UNEMAT) E-mail: laercio@unemat.br

Volume 3, Número $5 \quad$ Revista UNEMAT de Contabilidade

Jan./Jun. 2014

UNEMAT
} 
brasileiro e gera milhões de empregos. Há no Brasil, mais de um milhão de fazendas na atividade (BOTELHO, 2008).

A Contabilidade de Custos apresentou os métodos e a importância do controle dos custos de produção. Com base em informações geradas nos registros contábeis, os gestores terão mais segurança na tomada de decisão. Induzir as empresas rurais a direcionar suas ações a competitividade e ao aumento da produtividade.

A contabilidade está inserida no processo de gestão, não sendo mais vista somente como cumprimento das finalidades tributárias, oferece dados formais, concretos, confiáveis, os quais permitem o administrador planejar suas ações, dentro da organização. Neste contexto, a informação contábil foi utilizada como ferramenta aos gestores, que passaram a administrar com maior eficiência a atividade da empresa rural. Os métodos de custeio facilitam o controle dos custos e podem ser aplicados à atividade pecuária com eficácia.

No contexto nacional, a cadeia mato-grossense de bovinos de corte torna-se cada vez mais relevante. O Brasil possui um dos maiores rebanhos de bovinos no mundo, sendo o maior exportador de carne bovina. Entre as principais dificuldades no mercado externo da carne bovina, estão às barreiras tarifárias e não tarifárias. A adoção de práticas sanitárias adequadas é o desafio dos gestores rurais. Com o objetivo de consolidar a liderança do Brasil no cenário mundial e a abertura de novos mercados para exportação, na busca por melhores preços aos produtos.

O Serviço de Rastreabilidade da Cadeia Produtiva de Bovinos e Bubalinos (SISBOV) foi criado em 2002, em grande parte motivada pelas exigências européias por carne bovina rotulada e rastreada. Desde sua criação até a atualidade, o SISBOV passou por série de ajustes e transformações, resultantes em grande parte da pressão dos países compradores da carne brasileira, especialmente os europeus, que exigiam equivalência do SISBOV com os padrões de confiabilidade dos sistemas de rastreabilidade internacionais (LIMA, et al., 2007)

O objetivo desta pesquisa foi analisar se os custos da Fazenda Paraíso na produção de engorda proporcionam retorno financeiro no abate, de acordo com o valor de mercado. Os objetivos específicos deste estudo foram: Fazer levantamento dos custos de produção na Fazenda Paraíso; Caracterizar o sistema de bovinocultura aplicado na Fazenda Paraíso; Comparar o preço da arroba, com o custo de produção no sistema de engorda e fazer uma análise de custo, volume e lucro. 


\section{FUNDAMENTAÇÃO TEÓRICA}

\subsection{Contabilidade Rural}

Para Crepaldi (2005, p. 84) "Contabilidade Rural é um instrumento da função administrativa que tem como finalidade: controlar o patrimônio das entidades rurais; apurar o resultado das entidades rurais; prestar informações sobre o patrimônio e sobre o resultado das entidades rurais aos diversos usuários das informações contábeis".

A contabilidade é classificada conforme o ramo de atividade da empresa. Todas são distintas cada qual com as suas peculiaridades. "Quando estudada de forma genérica, a contabilidade é denominada contabilidade geral ou contabilidade financeira (MARION, 2007, p. 25)”. Sendo assim a contabilidade é qualificada como segue:

Contabilidade Agrícola: é a Contabilidade Geral aplicada as empresas agrícolas; Contabilidade Rural: é a Contabilidade Geral aplicada as empresas rurais; Contabilidade da Zootécnica: é a Contabilidade Geral aplicada as empresas que exploram a Zootécnica; Contabilidade da Pecuária: é a Contabilidade Geral aplicada ás empresas pecuárias; Contabilidade Agropecuária: é a Contabilidade Geral aplicada as empresas agropecuárias; Contabilidade da Agroindústria: é a Contabilidade Geral aplicada ás empresas agroindustriais (MARION, 2007, p. 26).

Conforme Marion (2007, p. 24) de maneira geral às atividades operacionais das empresas rurais é fundamentada em explorar a capacidade produtiva do solo por meio do cultivo da terra, da criação de animais e também na transformação de alguns produtos agrícolas. As atividades das empresas rurais podem ser divididas em: Produção vegetal atividade agrícola; Produção animal - atividade zootécnica; Indústrias rurais - atividade agroindustrial

Ainda para Crepaldi (2005, p. 25) a "empresa rural é a unidade de produção em que são exercidas atividades que dizem respeito a culturas agrícolas, criação de gado ou culturas florestais, com a finalidade de obtenção de renda".

Apesar de a atividade agrícola desempenhar papel fundamental no desenvolvimento do país, neste trabalho a ênfase foi para a produção animal - atividade zootécnica precisamente na pecuária de corte (criação de gado). Entende-se por gado “(...) animais geralmente criados no campo, para serviços de lavoura, para consumo doméstico ou para fins industriais e comerciais (MARION, 2007, p. 25)". Alguns exemplos de gados: bovinos, suínos, caprinos, eqüinos, ovinos, muares etc.

De acordo com Crepaldi (2005, p. 211) as pessoas associam pecuária ao gado vacum (bois e vacas), porém a criação de gado em geral diz respeito a animais que vivem em Volume 3, Número 5 Revista UNEMAT de Contabilidade 
coletividade (rebanho), podem ser bois e vacas, búfalos, carneiros, ovelhas e outros, as aves que incluem frango, pato, marreco, faisão, peru etc.

Como o Brasil dispõe de um dos maiores rebanhos bovinos do mundo e sua pecuária na bovinocultura representa uma atividade econômica de grande importância resolve-se dar prioridade a esta atividade para este estudo. De acordo com Freire, p. 154, apud Marion (2007, p. 25) "pecuária é a arte de criar e tratar gado”. “(...) embora não seja verdade absoluta, a administração das empresas ligadas ao agronegócio brasileiro, ainda se desenvolve dentro de critérios tradicionais que apresentam um padrão de desempenho restrito, considerando seu potencial global (CALLADO, 2006, p. 56)".

\subsection{Exercício Social na Atividade Rural}

O exercício social na atividade rural é bem diversificado, depende do ciclo operacional de cada atividade. Não segue o padrão das empresas, comercial, industrial e de serviço, cuja quais praticamente encerram junto com o ano civil em 31/12 (MARION, 2007, p. 26).

Ainda Marion (2007, p. 26) afirma que em qualquer mês do ano as empresas poderiam efetivamente fazer o encerramento do exercício social e a apuração do resultado. Uma vez que as empresas têm receitas e despesas durante todos os meses do ano. A opção para o mês de dezembro é pelo fato de ser o último mês do ano e também pela redução ou até interrupção da atividade operacional, férias coletivas, condições mais adequadas para o inventário das mercadorias.

Com as diferenças que existem no âmbito rural, tendo em vista que cada atividade depende de variáveis não controláveis, existem algumas exceções quanto às regras praticadas na contabilidade das empresas rurais.

$\mathrm{Na}$ atividade pecuária o exercício social não coincide com o ano civil. O término se dá logo após o nascimento dos bezerros ou do desmame (MARION, 2007, p. 28). É bem verdade que as empresas precisam se organizar para controlar ao máximo o nascimento dos bezerros. Analisar qual o período de maior fluxo, se programar com métodos auxiliares. Para então decidir qual é o período mais adequado para o encerramento do exercício social. Segundo Marion (2007, p. 28) "há empresas pecuárias que fixam o exercício social com base no mês seguinte em que concentram a venda das reses para o frigorífico. Esse critério é igualmente válido quanto ao nascimento dos bezerros". 
Quanto ao Imposto de Renda “(...) a Lei n” 7.450/85, tornou-o obrigatório, para todas as empresas, o exercício social coincidindo com o ano cível, ou seja, de 1\% a 31/12 (MARION, 2007, p. 29)".

Essa Lei não trouxe benefícios para a contabilidade rural. Conforme citado, o exercício social das empresas rurais concentra seu término em períodos diferentes durante o ano, cada qual com seus diferenciais.

\subsection{Tipos Jurídicos na Agropecuária}

De acordo com Marion (2007, p. 29) "na atividade rural encontramos duas formas jurídicas possíveis de exploração (...): pessoa física e pessoa jurídica”. Assim Crepaldi (2005, p. 84) conceitua da seguinte forma.

\footnotetext{
Pessoa física ou pessoa natural é o ser humano, o individuo (...) conforme o artigo $4^{\circ}$ do Código Civil Brasileiro. A Pessoa jurídica é um individuo de existência abstrata, que nasce da reunião de duas ou mais pessoas físicas ou jurídicas, que se associam com determinado fim. Serve para designar a existência legal de uma sociedade, corporação, associação ou instituição, que auferiu o direito de ter vida própria e isolada das pessoas físicas que a constituíram.
}

$\mathrm{Na}$ prática das atividades rurais a forma mais utilizada é de pessoa física, por ser menos onerosa. No caso de pequenas atividades se torna mais vantajosa ainda. Porque "as pessoas físicas tidas como pequeno e médio produtor rural não precisam, para fins de Imposto de Renda, fazer escrituração regular em livros contábeis, podem utilizar apenas a livro-caixa e efetuar uma escrituração simplificada (MARION, 2005, p. 29)".

De acordo com a Legislação do Imposto de Renda, as pessoas físicas que são consideradas grande produtor rural terão que fazer a contabilidade como pessoas jurídicas. Deverão fazer a escrituração contábil de toda movimentação da atividade rural. Contratando profissional contábil para tal operação (MARION, 2007, p. 29).

São consideradas microempresas as empresas que obtiver receita bruta anual igual ou inferior a R\$ 120.000,00 (cento e vinte mil reais). E são considerada empresa de Pequeno porte a empresa que obtiver receita bruta anual superior a $\mathrm{R} \$ 120.000,00$ (cento e vinte mil reais) e igual ou inferior a $\mathrm{R} \$ 720.000,00$ (setecentos e vinte mil reais) até 31/12/98. A Lei $\mathrm{n}^{\circ}$ 9.718/98 alterou esse valor par $\mathrm{R} \$ 1.200 .000,00$ (um milhão e duzentos mil reais), que começou a vigorar a partir de 01/01/99 (MARION, 2007, p. 198). 
Para melhor entendimento o valor da receita bruta da atividade rural são todas as vendas dos produtos na sua atividade operacional, deduzidos das vendas canceladas e os descontos concedidos. Esta receita bruta deverá ser comprovada mediante documentos utilizados habitualmente, “(...) tais como nota fiscal de produtor, nota fiscal de entrada, nota promissória rural vinculada à nota fiscal do produtor e demais documentos reconhecidos pelas legislações estaduais (MARION, 2007, p. 210)".

A empresa que se enquadrar no limite de receita bruta estabelecido em Lei que não precisa fazer a escrituração contábil como se fosse pessoa jurídica, terá apenas os seguintes livros de registros contábeis, conforme afirma Marion (2007, p. 198).

Livro caixa, no qual deverá estar escriturada toda a sua movimentação financeira, inclusive bancária. Livro de Registro de Inventario, no qual deverão constar registrados os estoques existentes no término de cada ano-calendário. Todos os documentos e demais papéis que serviram de base para a escrituração dos livroscaixas e Registro de Inventário.

Ainda Marion (2007, p. 210) complementa que "o resultado da exploração da atividade rural por pessoas físicas, a partir do ano-calendário de 1996, deverá ser feito mediante escrituração do livro-caixa, exceto para os contribuintes cuja receita anual (...) seja de valor até R\$ 56.000,00 (...)”. Assim as Atividades Rurais que podem obter benefícios fiscais, são as empresas que praticam operações destinadas ao setor da:

\begin{abstract}
Agricultura; pecuária; extração e exploração vegetal e animal; exploração de apicultura, avicultura, cunicultura, suinocultura, sericicultura, piscicultura e outros cultivos de animais; transformação de produtos decorrentes da atividade rural, sem que sejam alteradas a composição e as características do produto in natura, feita pelo próprio agricultor ou criador, com equipamentos e utensílios usualmente empregados nas atividades rurais, utilizando matérias-primas produzidas na área rural explorada (...); a partir de $1977,(. .$.$) o cultivo de florestas que se destinem ao$ corte para comercialização, consumo ou industrialização; a venda de sêmen de reprodutor e produção de embriões em geral (...) (MARION, 2007, p. 209).
\end{abstract}

As empresas que não se enquadram nas atividades relacionadas, sendo pessoa física ou jurídica não podem ser consideradas atividade rural. Portanto se priva dos benefícios auferidos a este tipo de atividade.

\title{
2.4 Contabilidade de Custos
}

Conforme Neves et al. (2008, p. 10) e Martins (2006, p. 19) a contabilidade de custos surgiu com o advento da Revolução Industrial. Até o momento só existia a contabilidade geral 
ou financeira praticado nas empresas comerciais. Essas empresas não fabricavam, apenas compravam e vendiam. Adaptar o modelo, que até então era suficiente para as empresas, não foi tarefa fácil para os contadores. Em razão das necessidades contábeis das indústrias que são bem complexas.

Iniciou-se novo modelo de contabilização a contabilidade de custos. Para Callado (2006, p. 55) "a prática da contabilidade de custos contempla a identificação, o registro, a acumulação e a organização dos diversos elementos relativos às atividades operacionais de um negócio e auxilia a administração no processo de tomada de decisões e de planejamento".

Devido à expansão do mercado de ações e da criação do IR, houve a criação de princípios básicos universais de Contabilidade que possibilitassem a comparação de demonstrações contábeis de empresas diferentes (e da mesma empresa em datas diferentes). Passou-se a focalizar o valor de fabricação ao invés da avaliação de estoques, como ocorria na contabilidade financeira (BATALHA, 2007, p. 433).

Entende-se por custo "gasto relativo à bem ou serviço utilizado na produção de outros bens e serviços; são todos os gastos relativos à atividade de produção (SILVÉRIO et al. 2008, p. 16)". Os custos necessitam ser classificados para cumprir os objetivos que se propõem. Assim são divididos quanto ao processo produtivo em custos diretos e custos indiretos. "Custos diretos são os custos apropriados aos produtos conforme o consumo (...). Custos indiretos são os custos apropriados aos produtos em função de uma base de rateio ou outro critério de apropriação (...) (MEGLIORINI, 2007, p. 9)".

Esse mesmo autor ainda classifica os custos conforme o volume de produção, em custos fixos e custos variáveis. Todos os gastos que decorrem da manutenção da estrutura produtiva da empresa, independente da quantidade que venha produzir respeitando o limite da capacidade instalada são denominados custos fixos. Os gastos que aumentam ou diminuem conforme o volume de produção é classificado como custos variáveis (MEGLIORINI, 2007, p. 10).
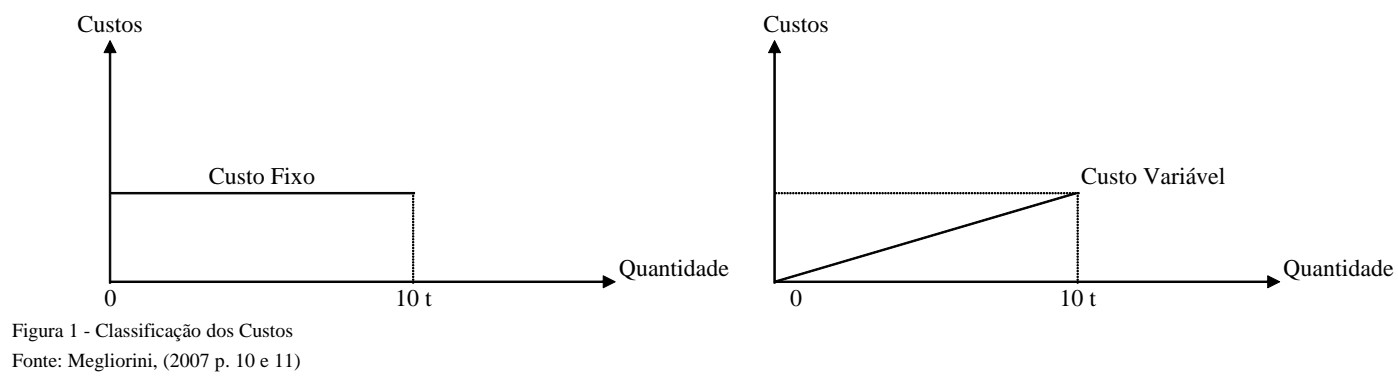

Fonte: Megliorini, (2007 p. 10 e 11$)$ 


\subsection{Método de Custeio por Absorção}

Esse método na contabilidade rural é conhecido também como Método de Custo. Marion (2007, p. 116) afirma que no método de custo “(...) todo o custo da formação do rebanho é acumulado ao plantel e destacado no Estoque". E ainda Crepaldi (2004, p. 88) conceitua que "Custeio por Absorção consiste na apropriação de todos os custos de produção para os produtos e ou serviços produzidos (...)". Estabelecer o custo ao produto é apropriar todos os gastos relativos à produção de um ou vários produtos. Este método de custeio também conhecido como custeio pleno apropria todos os custos sejam eles fixos ou variáveis ao produto, com exceção apenas das despesas do período (CREPALDI, 2004, p. 87). Este método deriva da aplicação dos princípios fundamentais de contabilidade e também é o único método aceito pela Legislação Comercial e Fiscal. Martins (2006, p. 197) enfatiza que na utilização do sistema de custeio por absorção “(...) não há, normalmente grande utilidade para fins gerencias no uso de um valor em que existem custos fixos apropriados".

A principal diferença na aplicação do método por Absorção está na separação de custos e despesas. As despesas são jogadas diretamente para o resultado do período e os custos, fixos e variáveis são atribuídos ao custo do produto. Assim os custos diretos e indiretos também são alocados ao custo de produção. O primeiro diretamente e o segundo por critérios de rateio (CREPALDI, 2004, p. 87; PADOVEZE, 2004, p. 333).

$\mathrm{Na}$ contabilização desse sistema de custeio pode verificar alguns passos que devem ser seguidos mediante as informações contábeis. São processos necessários na aplicação do método, com o objetivo de simplificar os registros.

\footnotetext{
Primeiro, é preciso separar os custos de produto do custo do período. Segundo, os custos diretos de produto são atribuídos aos produtos específicos, enquanto os custos indiretos são atribuídos a centros de custos. Terceiro, os custos indiretos são distribuídos do centro aos produtos de acordo com seu uso. A soma de custos diretos e custos indiretos distribuídos forma o custo do produto (CREPALDI, 2004, p. 90).
}

Como forma de entendimento do caminho a seguir para chegar aos custos e despesas, na apuração de resultado, no custeio por absorção. Os custos que são lançados ao resultado são os custos referentes aos produtos vendidos, o restante permanece no estoque final (CREPALDI, 2004, p. 94).

\subsection{Caracterização da Bovinocultura}


A economia mundial vem sofrendo modificações no decorrer dos anos. Tudo na busca de ganhar mercados. Essa mudança acontece por pressões políticas e comerciais.

Uma das fontes econômicas é a criação de bovinos que existe no mundo há muitos séculos. Fala-se que o boi foi um dos primeiros animais domesticados, por causa de sua utilidade na agricultura. Com a queda do Império Romano, a criação de gado diminuiu bastante na Europa, situação que durou até o século XVII. Algum tempo mais tarde com o advento da invenção da refrigeração industrial, em 1868, o consumo de carne se tornou popular com muita rapidez (A PECUÁRIA, 2007, p. 1).

A criação de gado vacum expandiu-se consideravelmente no continente americano, principalmente no Brasil, Argentina, Uruguai, Estados Unidos e México, por encontrar situação ecológica favorável. No Brasil, a criação de gado bovino foi importante no processo de desbravamento, de dilatação de fronteiras e de alimentação rica em proteínas (A PECUÁRIA, 2007, p. 2).

O gado bovino compreende três espécies principais: o boi comum (bos taurus), o zebu ou boi indiano (bos indians) e o búfalo (bubalus bubalis). Atende a duas finalidades básicas que é a pecuária de corte e a pecuária leiteira. Sendo que a primeira destinada ao abate para o fornecimento de carne. E a segunda destinada à produção de leite e derivados. $\mathrm{O}$ gado bovino foi introduzido no Brasil por volta de 1530 em São Vicente (SP) e logo após no Nordeste (Recife e Salvador), espalhando-se com o tempo por diversas regiões do país (A PECUÁRIA, 2007, p. 3).

A atividade pecuária e agrícola do Brasil durante anos se fez presente no cenário histórico como o principal pilar de sustentação da economia brasileira. Sustentando todo o período do processo de industrialização do país. A partir da década de 70, algumas situações contribuíram para a redução da margem de lucro das atividades rurais. O êxodo rural gerado pela industrialização, a evolução na legislação trabalhista, a criação comercial de outras espécies, o esgotamento dos recursos do solo juntamente com a falta de técnica pode ter contribuído (COELHO et al., 2006).

A pecuária de corte foi a mais atingida, o preço de venda da arroba do boi gordo reduziu pela metade enquanto que o custo de produção continuou o mesmo. Somente a partir de 1999, em razão de problemas sanitários em países concorrentes. O caso da vaca louca nos Estados Unidos em dezembro de 2003, permitiram a carne bovina brasileira ocupar o mercado internacional, se tornando a partir de 2004 o maior exportador mundial de carne bovina. $\mathrm{O}$ Brasil por possuir clima favorável, solos de boa qualidade, espaço geográfico benéfico e 
grandes áreas disponíveis. Contribuiu para obter vantagens frente aos concorrentes, produzindo carnes saudáveis com qualidade e em quantidade (COELHO et al., 2006).

De acordo com o IBGE (2006) a atividade pecuária brasileira ostenta o maior rebanho comercial do mundo, cerca de 205,9 milhões de cabeças. O Brasil ocupa a posição de o segundo maior produtor mundial de bovinos no mundo ficando atrás somente da Índia (USDA, 2007).

Segundo dados do Departamento de Agricultura dos Estados Unidos (USDA) o Brasil acessa cerca de $20 \%$ do mercado mundial de carne bovina. O consumo per capita é de 36,5 kg/ano. Perdendo apenas para os Estados Unidos com 45,6 kg/ano. Entretanto acima de todos os países da Europa (UE) e do Canadá que é de 31,7 kg/ano (MARION, 2007, p. 15).

A tabela 1, mostra as expectativas do Departamento de Agricultura dos Estados Unidos (USDA) para as exportações de carne bovina. Chamando atenção para o crescimento dos Estados Unidos (EUA) que vem recuperando seu espaço no mercado e do Brasil que desde 2004 é o maior exportador de carne bovina do mundo. Os maiores importadores da carne brasileira são: a Rússia, Egito, Reino Unido, EUA, Hong Kong com 330.277, 207.300, 113.747, 94.262, 69.437 toneladas anuais em equivalente-carcaça respectivamente (MDIC, adaptado por ABIEC, 2007).

Tabela 1 - Exportações de Carne Bovina para o Ano de 2007 - milhões toneladas.

\begin{tabular}{lccc}
\hline \multicolumn{1}{c}{ Pais } & $\mathbf{2 0 0 6}^{*}$ & $\mathbf{2 0 0 7}^{*}$ & Variações \\
\hline Brasil & 1945 & 1985 & $2,10 \%$ \\
Austrália & 1420 & 1495 & $5,30 \%$ \\
Índia & 750 & 800 & $6,70 \%$ \\
EUA & 523 & 680 & $30,00 \%$ \\
Argentina & 500 & 600 & $20,00 \%$ \\
Nova Zelândia & 540 & 570 & $5,60 \%$ \\
Uruguai & 510 & 520 & $2,00 \%$ \\
Canadá & 455 & 440 & $-3,30 \%$ \\
Europa & 200 & 200 & $0,00 \%$ \\
China & 90 & 85 & $-5,30 \%$ \\
México & 35 & 40 & $14,30 \%$ \\
Total & $\mathbf{6 . 9 9 6}$ & $\mathbf{7 . 4 5 4}$ & $\mathbf{6 , 5 0 \%}$ \\
\hline
\end{tabular}

Fonte: USDA/Scot Consultoria

*preliminar; **previsão

Tabela 2 - Produção, Rebanho e Abate de Bovinos no Brasil 1996 a 2007. 
Gestão de custos aplicada à bovinocultura de corte: o caso da fazenda Paraíso em Juina-MT Rosangela Nunes da Silva de Souza Laércio Juarez Melz

\begin{tabular}{ccccccc}
\hline Ano & Produção $^{\mathbf{1}}$ & $\begin{array}{c}\text { Variação } \\
\text { Acumulada } \\
(\boldsymbol{\%})\end{array}$ & Rebanho $^{\mathbf{2}}$ & $\begin{array}{c}\text { Variação } \\
\text { Acumulada } \\
(\boldsymbol{\%})\end{array}$ & Abate $^{2}$ & $\begin{array}{c}\text { Variação } \\
\text { Acumulada }^{(\%)}\end{array}$ \\
\hline 1996 & 6045 & 0 & 153,1 & 0 & 31,0 & 0 \\
1997 & 5820 & 3,87 & 156,1 & 1,92 & 29,1 & $-6,53$ \\
1998 & 6040 & $-0,08$ & 157,8 & 2,98 & 30,2 & $-2,65$ \\
1999 & 6270 & 3,59 & 159,2 & 3,83 & 31,3 & 0,96 \\
2000 & 6650 & 9,10 & 164,3 & 6,82 & 32,5 & 4,62 \\
2001 & 6900 & 12,39 & 170,6 & 10,26 & 33,8 & 8,28 \\
2002 & 7300 & 17,20 & 179,2 & 14,56 & 35,5 & 12,68 \\
2003 & 7700 & 21,49 & 189,1 & 19,04 & 37,6 & 17,55 \\
2004 & 8350 & 27,60 & 197,8 & 22,60 & 41,4 & 25,12 \\
2005 & 8750 & 30,91 & 202,7 & 24,47 & 43,1 & 28,07 \\
$2006 *$ & 8950 & 32,46 & 204,7 & 25,21 & 44,4 & 30,18 \\
$2007 * *$ & 9200 & 34,29 & 207,2 & 26,11 & 45,0 & 31,11 \\
\hline Fonte: Conselho Nacional da Pecuária de Corte (CNPC)(2007) & & &
\end{tabular}

Obs.: *Valor preliminar; ${ }^{* *}$ Estimativa; ${ }^{1}$ em milhões toneladas em equivalente-carcaça; ${ }^{2}$ milhões.

Com a criação do Fundo de Desenvolvimento da Pecuária (Fundepec) o setor da pecuária teve grande impulso. Os criadores perceberam a necessidade de investir mais em genética, saúde e alimentação animal (MARION, 2007, p. 16). Para o presidente da Fundepec o sucesso da pecuária fundamenta-se em fertilidade, obtendo maior número de nascimentos e

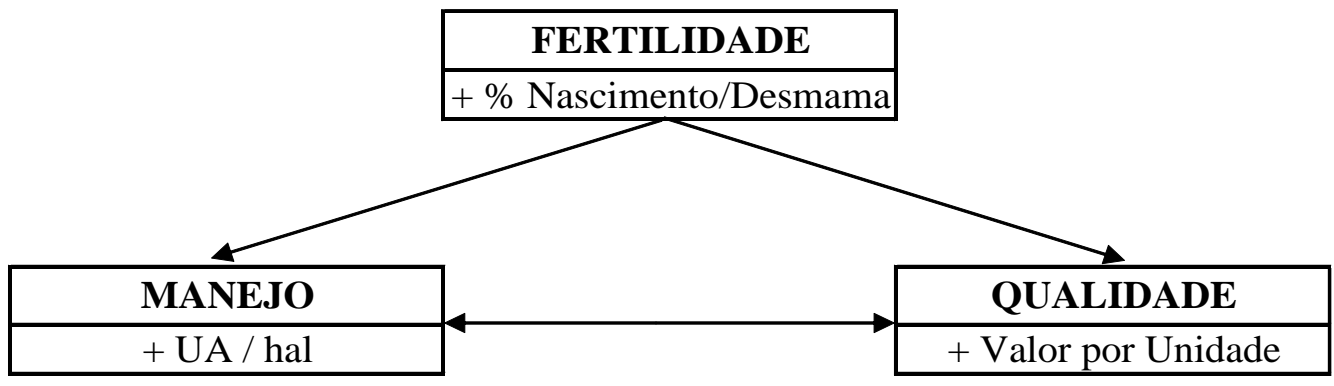

Figura 3 - O Sucesso da Pecuária

Fonte: Marion (2007, p.16)

desmamas; manejo, maior capacidade de animal por hectare; qualidade, melhor preço na venda.

Conforme Marion (2007, p. 16) “(...) está sendo realizado no país através do Programa de Qualidade Nelore Natural (PQNN) um dos mais ambiciosos projetos de valorização da pecuária nacional, cujo objetivo é garantir a integridade da qualidade de ponta a ponta da cadeia (...). Nelore Natural. Boi de Capim. Carne Saudável”. Proporcionando base de apoio aos produtores rurais. 
As principais áreas de criação de gado bovino no Brasil são: A Região Centro Oeste com o maior rebanho de bovino do país, responsável, sozinha por 34,2 \% do total brasileiro (IBGE, 2006) distribuídos por GO, MS, MT e DF. Sendo a pecuária do Centro Oeste predominante na criação extensiva de corte destinada na maior parte ao abastecimento do mercado paulista. Os preços das terras são mais acessíveis em relação aos do Sudeste e Sul e é próximo do maior centro de consumo do país. A Região Sudeste que possui o $2^{\circ}$ maior rebanho bovino do país distribuídos em MG, SP, RJ e ES. Nesta região predomina a raça zebu (Nelore, Gir, Guzerá), aparecendo raças européias e mistas, destinadas tanto ao corte como a produção de leite. Na Região Sul que possui o $3^{\circ}$ maior rebanho do país distribuído nos estados do RS, PR, SC. Se destaca por possuir o rebanho que além de numeroso é o de melhor qualidade no Brasil. O rebanho é constituído por raças européias (Hereford, Devon, Shorthorn) e conta com técnicas aprimoradas de criação e condições naturais favoráveis, como: relevo suave, pasto de melhor qualidade, clima subtropical com temperaturas mais baixas e chuvas regulares. Em $4^{\circ}$ lugar na criação de bovinos fica a Região Nordeste, distribuídos na BA, MA, CE, PE e PI. A pecuária bovina nesta região é extensiva de corte. Sendo difundida em toda região, mas a principal área pecuarista é o Sertão. A produtividade do rebanho nordestino é das mais baixas do país, tanto na carne como em leite. A Região Norte possui o menor rebanho bovino do país, concentrado principalmente no estado do Pará. No entanto foi o que mais cresceu no último decênio. Nesta região predomina a pecuária extensiva de corte (IBGE, 2007).

No Brasil a área destinada à pecuária extensiva, segundo o IBGE (2007), é de 225 milhões de hectares. Também é possível agregar mais produtividade a criação do gado sem recorrer ao confinamento. Como fazem os Estados Unidos e Austrália, países que compensam o tamanho relativamente pequeno do rebanho com a redução do tempo de engorda para até 20 meses, sendo que na criação extensiva o prazo é de três anos.

O rebanho bovino do Brasil é explorado para dois fins: leite e corte. A produção de leite vem em primeiro lugar e após as vendas dos bezerros, também conhecidos como "machos leiteiros" para recria e engorda como gado de corte. Esses bezerros não recebem nenhum tratamento especial, muitas das vezes atrasando o preparo para a venda do boi de corte. A média para engorda pode levar de quatro a cinco anos para o abate com 15 ou mais arrobas (CREPALDI, 2005, p. 211).

As principais raças encontradas no Brasil são: Angus, Hereford, Shorthorn, Devon e Nelore, Gir, Guzerá (indianas) e indu - brasileiras, Red polled, Normanda, Santa Gertudes e 
etc. No final do século XIX iniciou-se a importação de raças européias selecionadas, principalmente para o Sul do país, região que permitiu boa aclimatização e grande expansão. De acordo com o Conselho Nacional de Pecuária de Corte (CNPC, 2007) "no início do século $\mathrm{XX}$, alguns pecuaristas brasileiros importaram animais de raça Nelore da Índia, que por suas características adaptativas ao clima tropical dominou o cenário pecuário do país e até hoje é a principal raça de corte criada em todas as regiões brasileiras".

Conforme o Censo Agropecuário 2006 o Estado de Mato Grosso dispõe de área de 903.357.908 $\left(\mathrm{Km}^{2}\right), 141$ municípios e população estimada de 2.854.642, tendo como capital à cidade de Cuiabá.

O gado bovino foi introduzido no Estado de Mato Grosso na Capitania de Mato Grosso no século XVIII por volta de 1724. Quando o Governador da Capitania de São Paulo incentivou os criadores da Vila de Curitiba a conduzirem pontas de seu gado em direção ao Rio Cuiabá (SILVA, 2006, p. 101).

"Com o desenvolvimento da pecuária na fazenda de Camapuã além de cuidar do abastecimento das mansões atendia ainda algumas localidades espanholas como Montevidéu, Buenos Aires, Assunção e Concepción fornecendo gado em pé, carne seca, sebo, ossos e o couro que tinha grande importância na exportação (SILVA, 2006, p. 101)”.

As primeiras raças introduzidas no estado foram a Franqueira classificada como boa para produção de carne e leite (peso bruto de $750 \mathrm{~kg}$ ).

\begin{abstract}
A maior parte do gado bovino, eqüino e muar que adentrou a Mato Grosso no século XVIII foi das Missões Espanholas de Moxos e Chiquitos dando origem às primeiras fazendas de criar. Várias partidas de bois, vacas, cavalos e bestas entraram via Goiás na região de Cuiabá (rios São Lourenço, Coxim, Taquari e alagado do alto Paraguai) e Vila Bela da Santíssima Trindade, nas imediações até Casalvasco (SILVA, 2006, p. 105).
\end{abstract}

Neste contexto o Estado de Mato Grosso demonstrava muitas vantagens. O gado dispunha de pastos nativos em abundância, rico em capim-mimoso, capim de bezerro, o arroz do pantanal, capim-de-angola, assim como dezena de outras espécies que eram apreciadas pelas manadas.

A guerra do Paraguai (1865-1870) desestruturou a organização estabelecida em grande parte do território mato-grossense. As forças paraguaias avançaram do sul para o norte até Cáceres e grande parte da população se viu obrigada a abandonar suas terras, deslocando-se para Cuiabá. A economia das áreas invadidas e ocupadas pelos paraguaios, onde prevalecia à pecuária, foi em parte dizimada (MORENO, 2005, p. 25). 
Somente no século XX que o eixo econômico mato-grossense desloca-se para a agropecuária. Neste momento Mato Grosso é privilegiado também com agricultura de prestígio sendo ela de: milho, algodão, mandioca, fumo, rapadura e aguardente. A pecuária tornou-se excelente negócio, por volta de 1920 estima-se um rebanho de 43 mil cabeças. Nesta fase as raças introduzidas foram Franqueira, Pantaneira ou Cuiabana, o Zebu e o China. As fazendas eram enormes, exemplo disso havia uma fazenda com área de 176.853 hectares (SILVA, 2006, p. 107).

A criação do gado foi aumentando, logo deram lugar ao ciclo econômico das charqueadas que tiveram o maior sucesso por volta de 1923 onde foram distribuídas por todo o Estado. "Neste período o charque produzido em Mato Grosso foi comercializado nas praças do Rio de Janeiro, Bahia, Pernambuco, Pará e se exportou para a região platina, Cuba e Inglaterra (SILVA, 2006, p. 114)”.

O ciclo econômico das charqueadas teve um período curto. Logo sucedeu sua queda após a chegada da Estrada de Ferro e dos boiadeiros paulistas. Conforme Silva (2006, p. 110).

\footnotetext{
No início do século XX, a implantação da estrada de ferro no sul mato-grossense possibilitou um maior desenvolvimento da pecuária na região. (...) A via férrea valorizou a terra, facilitou o povoamento, o transporte do gado, ajudou a introduzir reprodutores de estirpe para melhorar a genética dos rebanhos e transferiu o eixo econômico da cidade de Corumbá pra Três Lagoas. Três Lagoas passou a ser uma espécie de feira para o comércio de gado, onde se vendia de 15 a 20 mil cabeças de gado por ano.
}

Esta situação acabou fortalecendo politicamente e economicamente, os pecuaristas do sul mato-grossenses. A economia começou a depender dos capitais advindos dos frigoríficos paulistas. Sendo Três Lagoas o principal município de fornecimento de gado em pé, como era comercializado na época.

Segundo Moreno et al. (2005, p. 158) a pecuária se manteve como a principal atividade econômica do Estado de Mato Grosso até meados de 1970. Quando a agricultura passou a apresentar maiores rendimentos.

A predominância da criação do gado em Mato Grosso é extensiva principalmente no Pantanal. Com as exigências do mercado de exportação a pecuária vem lutando para modernizar. Sem deixar de usufruir de tudo que o Estado tem de melhor, as pastagens naturais. Isso pode possibilitar a ampliação das exportações do gado bovino com certificação 
ambiental, o "selo verde" que é exigência da maioria dos países consumidores que querem consumir carne sem a utilização de produtos químicos para engorda.

"Somente em 2000 o Estado de Mato Grosso foi considerado habilitado a exportar carne bovina in natura para o mercado europeu (MORENO, 2005, p. 158)".

O Estado foi considerado "livre de aftosa com vacinação", juntamente com São Paulo, Paraná, Minas Gerais e Goiás, que integram o Circuito Pecuário do CentroOeste, pela Organização Internacional de Epizootias (OIE), instituição ligada à Organização das Nações Unidas (ONU), que regulamenta a importação e exportação de produtos de origem animal. Este certificado credencia Mato Grosso a exportar carne in natura para a União Européia, Estados Unidos e Ásia (MORENO, 2005, p. 158).

Ainda Moreno (2005, p. 159) afirma que algumas técnicas foram introduzidas para melhorar a pecuária em Mato Grosso tais como: a inseminação artificial, confinamento ou semi-confinamento e o manejo das pastagens. Tudo isso incentivado pelo Programa MatoGrossense de Melhoramento da Pecuária (PROMMEPE). Com a intenção de melhorar a carne bovina do Estado e enquadrar nos parâmetros de exigências do mercado internacional. O abate da carne bovina é feito nos frigoríficos e abastece o centro de consumo interno no Estado de São Paulo assim como alguns municípios que estão habilitados a exportar para o mercado europeu.

"O rebanho bovino sempre ocupou a maior parte das terras exploradas com atividades agropecuárias no Estado de Mato Grosso. Em 1995, abrangia mais de 21 milhões de hectares, $90 \%$ do total da área destinada à agropecuária (MORENO, 2005, p. 159)”. De acordo com o último censo de 2006 a área de pastagens naturais no estado de Mato Grosso é de 22.809.021 hectare.

Tabela 4 - Mato Grosso - Efetivos de Bovinos - 1985, 1995, 2003, 2007.

\begin{tabular}{llccc}
\hline Anos & 1985 & 1995 & 2003 & 2007 \\
\hline $\mathbf{N}^{\mathbf{0}}$ de animais & 6.545 .956 & 14.438 .135 & 24.613 .718 & 25.683 .031 \\
\hline
\end{tabular}

Fonte: IBGE, 1991, 1997; IBGE, PPM, In: MATO GROSSO, 2005.

Fonte: Produção da Pecuária Municipal 2007.

O Estado de Mato Grosso vem se consolidando no mercado, desde o ano de 2000 ultrapassou o efetivo do Estado de Goiás e Mato Grosso do Sul. Passando a ocupar a primeira posição como o maior produtor de carne bovina do país. A atividade de pecuária de corte continua sendo a principal, tendo apoio da maioria dos produtores que optaram por cria e recria (MORENO, 2005, p. 159 e IBGE 2007). “A pecuária é desenvolvida em propriedades 
de todos os tamanhos, principalmente nas médias e grandes, sendo que os estabelecimentos acima de 1000 hectares concentram mais de 50\% do efetivo do Estado (MORENO, 2005, p. 159)".

Tabela 5 - Concentração do Rebanho no Estado de Mato Grosso.

\begin{tabular}{|c|c|c|}
\hline Região & $\begin{array}{l}\text { Percentual do } \\
\text { Efetivo Total }\end{array}$ & Municípios com maior produção \\
\hline $\begin{array}{l}\text { Norte de Mato- } \\
\text { grossense }\end{array}$ & $38,20 \%$ & $\begin{array}{l}\text { Juara (maior), Alta Floresta, Juina, Paranatinga, } \\
\text { Colider, Nova Canaã do Norte, Brasnorte, } \\
\text { Castanheira, Comodoro e Guarantã do Norte }\end{array}$ \\
\hline $\begin{array}{c}\text { Nordeste } \\
\text { Mato-grossense }\end{array}$ & $20,50 \%$ & $\begin{array}{l}\text { Barra dos Garças, São José de Xingu, Água Boa, } \\
\text { Vila Rica, Canarana, Cocalinho, Nova Xavantina, } \\
\text { São Félix do Araguaia, Ribeirão Cascalheira e } \\
\text { Araguaiana. }\end{array}$ \\
\hline $\begin{array}{c}\text { Sudoeste } \\
\text { Mato-grossense }\end{array}$ & $17,90 \%$ & $\begin{array}{l}\text { Vila Bela da Santíssima Trindade, Pontes e } \\
\text { Lacerda, Porto Espiridião, Barra do Bugres, } \\
\text { Tangará da Serra e Araputanga. }\end{array}$ \\
\hline $\begin{array}{c}\text { Centro-Sul } \\
\text { Mato-grossense }\end{array}$ & $12,20 \%$ & Cáceres, Santo Antônio de Leverger e Poconé. \\
\hline $\begin{array}{l}\text { Sudeste Mato- } \\
\text { grossense }\end{array}$ & $11,20 \%$ & Rondonópolis, Poxoréo, Pedra Preta e Itiquira. \\
\hline
\end{tabular}

De acordo com Bonfim (2007) as principais estratégias do Instituto de Defesa Agropecuária (Indea) e da Secretaria de Desenvolvimento Rural de Mato Grosso (Seder/MT) é criar comitês de sanidade animal em áreas de assentamento rural em parceria com a Federação dos Trabalhadores da Agricultura (Fetagri) e reativar os Conselhos Municipais de Erradicação da Febre Aftosa. Para garantir índice ainda maior de imunização do rebanho bovino em todo o Estado de Mato Grosso. Desta forma acredita-se que o cerco vai fechar em torno dos pecuaristas acomodados em relação ao combate a doença. O objetivo é ganhar novos mercados internacionais e melhorar o índice de sanidade. A cada dia, segundo Pereira (2008), as barreiras no mercado internacional deixam de ser tarifárias e passam a ser sanitárias.

A cidade de Juína onde se caracteriza o objeto de estudo está localizada no interior do Estado de Mato Grosso a $700 \mathrm{~km}$ da capital, faz divisa com as cidades de Castanheira, Brasnorte, Aripuanã e Vilhena. Possui Área de unidade Territorial de $\left(\mathrm{Km}^{2}\right)$ 26.251, população de 38.422 aproximadamente (IBGE, 2007). 
De acordo com o Censo 2006 a área de pastagens é de 248.538 hectares, área de matas e florestas 395.856 hectares. Possui rebanho de 532.921 cabeças, ficando entre os dez maiores produtores de carne bovina do Estado. A perspectiva da pecuária é bastante promissora, tendo em vista o asfaltamento da BR MT-170, alcançando Juína e ligando-a ao mercado nacional, viabilizando a construção de frigoríficos. O número de propriedades rurais é bem significante 2.397, dessas 2.021 são para criação de bovinos. As médias das propriedades são acima de 500 hectares. Superando os 100 hectares dada a Legislação Ambiental.

Dispõe de três Frigoríficos, Independência que abate cerca de 700 cabeças ao dia, aproximadamente 17.000 cabeças mensais. Tendo como centro de distribuição a cidade de Cajamar-SP. O Frigorífico Frigoforte que abate média de 2000 cabeças mensais. Porém mata somente vacas, compradas em Juína e região, dessas apenas 200 cabeças são consumidas em Juína. O restante vai para centro de desossa em Rondonópolis e vendido em todo o Estado e o Frigorífico São Francisco que abate em média 1500 cabeças mensais, vendido em Juína e região.

\subsubsection{Carne Bovina}

A carne bovina é a mais consumida no Brasil e a terceira mais consumida no mundo (depois das carnes de porco e de frango). A terminologia normalmente empregada em pecuária é: Touro o macho não castrado, a partir de dois anos, destinado à reprodução; Vaca é a fêmea depois da primeira parição; Os machos castrados são chamados novilhos de corte ou, se destinados à tração, bois; Bezerros (ou terneiros) são os recém-nascidos até a desmama; No Brasil central, da desmama aos 24 meses a denominação comum é garrote. A fêmea, do ponto de enxerto até a primeira cria, denomina-se novilha.

O sistema utilizado na reprodução de bovinos é de monta natural livre, monta natural controlada ou inseminação artificial e monta parcialmente controlada. Monta natural livre é a mais usada: nela, o reprodutor permanece o tempo todo com as vacas; Monta natural controlada ou inseminação artificial: nesse sistema a vaca é observada seu cio e é levado ao reprodutor ou é inseminada; Monta natural parcialmente controlada: nesse sistema o reprodutor permanece com a vaca algum período do dia (CREPALDI, 2005, p. 212).

\subsubsection{Pastagens}


Quanto às pastagens pode ser natural que é o pasto nativo. São áreas não cultivadas onde se explora todo o potencial natural e a criação do gado é extensiva. Ao passo que a pastagem artificial é totalmente ao contrário, os pastos são cultivados. O solo é preparado através de destocamento, arações, adubações, gradagem, irrigação, plantação ou semeadura, a criação do gado bovino é intensiva.

De acordo com o dicionário Aurélio "forragem é qualquer planta ou grão para alimentação de gado". As forragens podem ser conservadas nas formas de feno ou silagem. Auxilia na manutenção do sistema de produção de carne e leite. O processo de ensilagem é a melhor maneira de conservação das forragens em seu estado verde, úmido, fazendo-as fermentar. Uma vez que este processo pode surtir efeito positivo ou negativo. Assim o produtor rural deve atentar para uma série de cuidados e optar pela melhor forma possível. Com o objetivo de conseguir a estabilidade do produto. Teoricamente, qualquer planta pode ser ensilada, no entanto algumas forragens apresentam maiores benefícios que outras.

Como exemplos podem ser citados: capim elefante (Pennisetum purpureum, Schum), também conhecido como capim-napier, Cameron, mineiro. Todos esses podem ser usados na produção da silagem (CREPALDI, 2005, p. 212).

De acordo com Crepaldi (2005, p. 213) feno é "a erva ceifada e seca utilizada na alimentação dos animais (...). Possui uma composição variada, dependendo da espécie vegetal, da forrageira empregada, se gramínea ou leguminosa, etc. (...)”.

\subsubsection{Sistema de Criação}

Conforme Araújo (2008, p. 53) existem três tipos de sistemas na criação de animais: intensivo, extensivo e semi-intensivo ou semi-extensivo.

O sistema intensivo "refere-se à criação de animais de forma intensiva, caracterizados por utilização de tecnologias mais sofisticadas, maior investimento em construções e alimentação (...), maior dedicação dos trabalhadores, menor espaço disponível, maior assistência etc., (ARAÚJO, 2008, p. 53).

Ainda para este autor os principais resultados das explorações intensivas são: produtividade maior por área e por animal, rapidez de ganhos, mais facilidade para controlar os rebanhos. O ganho ou perda também por unidade de tempo é mais rápido. Neste tipo de sistema a probabilidade de doenças é maior, entretanto como o contato com os trabalhadores é mais próximo, o problema é detectado com grau de eficiência grande. 
Para Marion (2007, p. 21) o sistema intensivo consiste na formação de pastagens artificiais adequadamente adubadas e até irrigadas. Na melhoria tanto das condições de alimentação (arraçoamento, sal, minerais etc.), associando pasto+suplementação, ou pasto+confinamento, melhorando as questões sanitárias pela aproximação do curral com o rebanho e na introdução de novas raças produtivas conforme cada região, substituindo os gados nativos.

No sistema extensivo os animais são criados soltos em grandes espaços. A alimentação é totalmente a pasto, os resultados geralmente são mais lentos do que os desejados. Há poucos investimento em construções e os cuidados também são menores. As carnes podem assumir sabores diferenciados (ARAÚJO, 2008, p. 54).

Conforme Marion (2007, p. 20) no sistema extensivo geralmente os animais são criados em pastos nativos ou cultivados, depende totalmente de recursos naturais. Este sistema é caracterizado de baixa lotação. Não há planejamento adequando para abrigar todos os animais e também há ausência de forragens. O manejo sanitário é somente em calendários de vacinação inseridos na região que localiza a propriedade. O manejo zootécnico praticamente não existe. É um sistema utilizado em áreas recém formadas.

No sistema semi-intensivo os animais são criados parte do tempo solto e parte do tempo confinado, usufruindo do espaço disponível e ao mesmo tempo utilizando tecnologia. Usando rações balanceadas e se aproveitando de todas as vantagens do sistema intensivo e extensivo. Neste sistema os animais permanecem a maior parte do dia solto, recebem complemento de sua alimentação nos cochos e pode ficar presos a noite (ARAÚJO, 2008, p. $54)$.

De acordo com Marion (2007, p. 20) a inviabilidade técnica versus econômica dos sistemas intensivos e extensivos pela degradação das forrageiras ou pastagens. Faz com que o produtor que pretende manter-se no mercado adote este sistema. Em que se faz a implantação de forrageiras, cuja qual sofre racionalidade nas divisões de pastagens. E que leva a maior capacidade de área de UA/ha/ano. Possibilita manejo mais adequado do rebanho, além de vacinações obrigatórias, vermifugação, mineralização e acompanhamento zootécnico do rebanho.

\subsubsection{Manejo}


Araújo (2008, p. 54) conceitua manejo dos rebanhos como "o conjunto de práticas racionais adotadas nas criações, com a finalidade de produzir animais de forma econômica".

Para um bom manejo precisa de investimentos, muito trabalho, conhecimentos técnicos e procedimentos adequados no quesito atendimento as necessidades dos animais. De forma que todo o processo de produção tenha controle, de todos os gastos de produção.

Saber conduzir o manejo é muito relevante. Uma vez que uma propriedade bem administrada proporciona maior produtividade. O produtor e os trabalhadores terão maiores rendimentos. Os animais também são beneficiados, tornando a produção mais viável e lucrativa impulsionando os produtores nas suas atividades.

Ainda para Araujo (2008, p. 55) no processo de manejo.

\begin{abstract}
O controle de doenças é feito prioritariamente de forma preventiva principalmente com animais tolerantes a uso de vacinas, com programas preestabelecidos e seguidos com rigor (...). O conforto dos animais é muito importante para se ter animais saudáveis bem alimentados e menos sujeitos a doenças e endo e ectoparasitas. Normalmente, animais que tem conforto se alimentam melhor, são mais resistentes a doenças e são mais produtivos. O empreendimento tem de ser lucrativo. Portanto, as práticas de manejo devem procurar integrar eficiência com minimização de custos.
\end{abstract}

Controlar, planejar e analisar a atividade rural é pensar no futuro da empresa. Marion (2007, p. 23) classifica manejo dos rebanhos como pastoreio. Que pode ser pastoreio rotativo (em rodízio) e pastoreio continuo. Pastoreio rotativo - é quando em algum momento interrompe-se o pastoreio, mantendo o pasto livre por determinado período. O pasto é dividido em piquetes e em seguida insere o pastoreio rotativo. Desta forma permite que o proprietário racionalize a produção de forragens, unificando a maior produção de forragens com a maior qualidade nutricional. Considera-se como medida satisfatória uma área de $70 \mathrm{~m}^{2}$ de pastagem por animal ao dia. A variação média para descansar o pasto é de 25 a 35 dias dependendo da forrageira. Esse tipo de processo é moderno e se bem conduzido leva a perpetuação da forrageira, não precisando fazer reforma. O meio ambiente também é beneficiado reduzindo totalmente o processo de degradação ambiental, como acontece no pastoreio contínuo. Pastoreio contínuo - é o inverso do pastoreio rotativo, o gado é mantido permanente e sem interrupção num mesmo pasto durante todo o ano. Entretanto nos dois tipos de pastoreio seja rotativo ou contínuo é de costume separar os animais em lotes distintos, conforme a classificação do rebanho. Sendo assim pode ter lote de vacas em cria, de animais de engorda, outro de bezerros etc. Para ambos os pastoreios um dos aspectos fundamentais é o planejamento do montante de cabeças por hectare, evitando o excesso de animal paro o pasto 
que se tem disponível, consolidando em maior produtividade. Daí a preocupação dos produtores, em manter o controle em termos de unidade animal por hectare, para não ultrapassar o limite máximo e sim conseguir o ideal por pasto.

\subsubsection{Tipos de Atividade na Pecuária}

De acordo com Crepaldi (2005, p. 213) a atividade pecuária se classifica em: Cria - a atividade principal é a produção do bezerro que é vendido após o desmame normalmente uma vez ao ano; Recria - a partir do bezerro desmamado que varia de um ano a dois anos, produz e vende o novilho magro para engorda; Engorda - é a atividade denominada de invernista, que a partir do novilho magro, produz o novilho gordo para vendê-lo, este processo demora de dois anos a três anos.

Ainda Marion (2007, p. 22) denomina que há produtores que fazem combinações de várias fases obtendo o seguinte resultado: Cria, Cria-recria, Cria-recria-engorda, Recria, Engorda.

Assim a atividade cria-recria cai à medida que a empresa cresce, ficando somente a recria. A atividade cria-recria-engorda é sistema integrado que aumenta conforme o tamanho da empresa. Na verdade o que influi é que a atividade pecuária denomina-se em três fases, cria, recria e engorda. Que vai do bezerro desde o nascimento na propriedade rural, até o momento da venda para abate, já gordo na fase adulta.

\section{METODOLOGIA}

Esta pesquisa foi realizada com base em dados bibliográficos coletados de livros e artigos científicos, concepção de pensadores a respeito dos temas que envolvem a Contabilidade de Custos, Contabilidade Rural e a Pecuária de Corte. Foi feito estudo de caso na Fazenda Paraíso em Juína no Estado de Mato Grosso. Os estudos foram concentrados no sentido de obter o maior conhecimento possível sobre as teorias a cerca do controle dos custos de produção na atividade de bovinocultura de corte. E ao sistema utilizado na propriedade.

Foram aplicadas entrevistas com o gerente e o proprietário da Fazenda. Teve a observação direta e também se coletou dados documentais extraído da empresa. Houve a aplicação de recursos metodológicos, com a finalidade de analisar a aplicabilidade da gestão dos custos de produção na pecuária de corte. 
A pesquisa ocorreu no período de agosto de 2008 a fevereiro de 2009. Os dados coletados foram referentes ao ano de 2008. O método de custeio aplicado para este trabalho foi o Custeio por Absorção.

Em relação aos objetivos a pesquisa foi descritiva, porque busca conhecimento do problema pesquisado com o objetivo de construir idéias flexíveis ao fato estudado. Conforme Gil (2007, p. 42) "as pesquisas descritivas tem como objetivo primordial a descrição das características de determinada população ou fenômeno ou, então, o estabelecimento de relações entre variáveis". Os procedimentos adotados foram mais quantitativos.

\section{ANÁLISE DOS RESULTADOS}

Nas seções a seguir apresentam-se os resultados da investigação realizada na Fazenda Paraíso. Que procurou se prender a todas as informações sobre os gastos relativos à produção do gado de corte e também ao modelo aplicado na criação dos bovinos. Sendo que a atividade operacional da empresa se estabelece na compra de garrotes na média de 12 (doze) arrobas acima. Da criação ao abate o período varia de um a dois anos não mais que isso. O peso para abate geralmente fica na média de 17 (dezessete) arrobas.

\subsection{Visão e missão}

A visão e missão da Fazenda Paraíso são bem específicas, uma vez que a missão define e direciona as atividades da empresa na busca por alcançar os objetivos já elaborados. E a visão viabiliza argumento que capacita enxergar a empresa atuando no futuro.

Ambas são imprescindíveis para as empresas de sucesso. Mostra qual o papel da empresa na sociedade e qual seus objetivos. Motiva as pessoas a cumprir o proposto e também a sua superação. Visto que a missão e a visão devem ser claras e objetivas naquilo que se propõe na empresa rural.

Sendo assim a empresa define a sua missão em lucratividade sustentável e a visão produzir com qualidade e em quantidade beneficiando a sociedade e o meio. Busca o fortalecimento da empresa com colaboradores focados no seu objetivo.

\subsection{Caracterização da Fazenda Paraíso}


A Fazenda Paraíso localiza-se na BR 170, km 45 no município de Juína Estado de Mato Grosso sentido ao município de Brasnorte próximo ao Rio Juruena, aproximadamente $10 \mathrm{~km}$. Em visita à Fazenda foi esclarecido o objetivo deste trabalho e para qual fim. Os dados foram coletados mediante entrevistas com o gerente e o proprietário, e também por meio de documentos da fazenda, referente ao ano de 2008. A atividade operacional praticada é a pecuária de engorda. Esta propriedade se enquadra no quesito grande propriedade rural. Das fazendas do proprietário esta foi à escolhida por ser a maior e de fácil acesso. $\mathrm{O}$ asfaltamento recente da BR 170 facilitou bastante a locomoção à fazenda.

A área de estudo é de 2.400 alqueires, desses 1.200 alqueires é formado por pastagens da espécie Brizantã, MG5, Mambassa. Possui um plantel de 4981 cabeças, a pastagem é dividida em 38 pastos na média de 35 alqueires cada e quatro piquetes para melhor desenvolvimento do manejo. Todos os cochos são cobertos com 5 metros de cumprimento. Tendo curral com a medida de 60x54, com oito repartições, com balança, tronco, cobertura de 60x12, embarcador, com quatro mangas de 30x40 e outra de 110x160.

Há barracão de 18x32, casa sede de $14 \times 12$, que além de abrigar o gerente serve de escritório da fazenda também. Existem mais duas casas para os funcionários e a terceira que serve de cantina da Fazenda. Em todas as casas há energia. Borracharia completa, motor estacionário. Tanque de combustível com bomba com capacidade para 5.000 litros. Água encanada nas casas com caixa de água de 20.000 litros, vinda de poço artesiano. Ambas as construções são de madeira.

Quanto aos veículos a fazenda possui trator 292 Massey Ferguson com grade roçadeira, calcariadeira, plantadeira; Toyota bandeirantes; motocicleta Yamaha XTZ 125. A fazenda tem pista de 800 metros de cumprimento toda cascalhada e baloada.

O Sr. Roque Silva de Oliveira Gerente da Fazenda é quem faz as compras dos animais, da raça zebu e cruzamento industrial. Esses animais são criados da seguinte forma: Logo após a chegada dos animais na fazenda é pesado e separado por variação média de peso de 30 quilos. Desverminado marcado com carimbo do ano e o mês da compra, (O motivo deste tipo de marcação é para identificar o tempo que o boi permanece na Fazenda, porque tem boi que não atinge o peso no período pré-estabelecido pela empresa. Geralmente é de dois anos, assim o boi é abatido sem alcançar as 15 arrobas, sendo vendido como valor de vaca).

Em seguida os animais são levados para o pasto separadamente por peso. Esse gado recebe tratamento alimentar com proteinado por 90 dias. Para que o gado se recupere rápido da perca de peso com o transporte. Após esse período os animais que der menos de $360 \mathrm{Kg}$ 
são encerrados esse tratamento com proteinado e continua somente com pasto e sal mineral. A administração acha que não é viável continuar com tratamento que é mais oneroso (proteinado) com animais que não alcançaram o peso nesse período.

Todos os bois são pesados a cada 90 dias, aqueles que pesarem $360 \mathrm{Kg}$ a $390 \mathrm{Kg}$ que ainda não foram castrados serão castrados. E continuarão com o tratamento do proteinado. A partir de $400 \mathrm{Kg}$ a variação média de peso que norteia a separação do pasto é de $15 \mathrm{Kg}$ de um lote para o outro. Esses lotes são alocados de 80 a 100 cabeças por pasto. Nessa separação admite também a raça. São separados pra observar qual a raça que ganha mais peso.

O tratamento com proteinado acontece todos os dias no período da manhã, direto nos cochos. Quando os lotes de boi alcançam o peso de $460 \mathrm{~kg}$, continua o tratamento por mais 30 dias. É pesado novamente e aquele animal que alcança ou passa de $480 \mathrm{~kg}$ vai para o abate. O animal que não alcançou o peso continua o tratamento por mais 30 dias é pesado novamente e vão todos para o abate independente do peso.

A empresa compra os animais quando o preço está viável em qualquer época do ano. De preferência de criadores maiores, porque geralmente eles possuem melhores rebanhos, em virtude de maior conhecimento genético. O gerente compra o gado bovino por toda região, Castanheira, Aripuanã, Colniza, Juruena, Brasnorte e Juína.

O frete dos animais à Fazenda é por conta do proprietário. Geralmente a compra se realiza com lotes acima de 50 cabeças. A empresa acredita que lotes menores não compensam o frete e a disponibilidade do seu gerente. Porém a maioria das compras acontece com lotes acima de 150 cabeças.

O ano de 2008 foi de muitas transformações na pecuária. O preço dos animais bovinos variou bastante influenciando na apuração dos custos de produção. A arroba do boi teve alta que há muito anos não ocorria. Assim motivou os pecuaristas a investir no negócio, uma vez que se tornou bem mais rentável. Em virtude dessas mudanças as casas que vendem produtos agropecuários multiplicaram, bem como os preços dos produtos, interferindo no custo de produção. Os produtos veterinários da Fazenda em sua maioria são comprados na capital, em grandes quantidades com a finalidade de conseguir melhores preços e conseqüentemente diminuir os custos.

A Fazenda Paraíso uma vez ao ano reforma os pastos na média de 70 alqueres. A reforma é realizada da seguinte forma: o pasto é todo calcareado, adubado e é plantando novas sementes. 
A empresa conta com 8 (oito) colaboradores: 1gerente, 3 vaqueiro, 1 tratorista, 1 carpinteiro, 1 caseiro e 1 cozinheira, todos são registrados.

A comercialização do plantel aconteceu praticamente durante todos os meses do ano. Os animais foram vendidos aos frigoríficos numa média de 5 cargas acima. O fluxo maior ocorreu no período da seca, de julho a novembro quando geralmente se paga o melhor preço na arroba do boi gordo.

\subsection{Gastos na Fazenda Paraíso}

Com base em dados fornecidos pelo gerente da Fazenda foi possível conhecer os custos de produção, dado esse que é foco deste estudo.

As informações foram coletadas a partir de documentos e entrevistas com o gerente da Fazenda. Os custos de produção do gado bovino mencionados neste estudo de caso referem-se ao ano de 2008, para um plantel de 4981 cabeças. Todos os gastos foram analisados cuidadosamente no sentido de classificá-los de forma correta. Conforme conceitua Silvério e V. (2008, p. 16) custo é "gasto relativo à bem ou serviço utilizado na produção de outros bens e serviços; são todos os gastos relativos à atividade de produção”. Que são divididos em custos diretos e custos indiretos conforme necessário ou ainda em custos fixos e custos variáveis de acordo com o volume de produção. O sistema de custeio aplicado foi o Custeio por Absorção. Na Fazenda a distribuição dos gastos de produção e as receitas são feitas em planilhas do excel e posteriormente registrado pela contabilidade da empresa rural.

Observa-se na Tabela 5, referente ao primeiro semestre, que o custo de produção total foi de $\mathrm{R} \$ 309.227,00$. Na análise vertical destaca-se maior volume de gasto no item proteinado e salários/encargos. Representando aproximadamente $27,85 \%$ e $13,79 \%$ respectivamente do total dos custos de produção neste período.

Nos custos mensais se destaca o mês de fevereiro com o maior custo. Este aumento se sucedeu mediante a compra de sal, que favoreceu meses subsequentes, o total foi de R\$ 69.343,00. Representando 22,5\% do total dos custos de produção do período.

Tabela 5 - Distribuição dos Custos de Produção Bovino no $1^{\circ}$ Semestre de 2008. 
Gestão de custos aplicada à bovinocultura de corte: o caso da fazenda Paraíso em Juina-MT

Rosangela Nunes da Silva de Souza Laércio Juarez Melz

\begin{tabular}{|c|c|c|c|c|c|c|c|c|}
\hline \multicolumn{3}{|l|}{ Custos/Produção } & \multicolumn{3}{|c|}{ Valores Mensais em (R\$) } & \multirow[b]{2}{*}{ Jun } & \multirow[b]{2}{*}{ Totais } & \multirow[b]{2}{*}{$(\%)$} \\
\hline Classificação & Jan & Fev & Mar & Abr & Mai & & & \\
\hline Energia & 582 & & 259 & 536 & 369 & 314 & 2.060 & 0,67 \\
\hline Salários & 6.081 & 6.332 & 4.095 & 6.378 & 8.431 & 6.826 & 38.145 & 12,34 \\
\hline Encargos & 1.015 & 735 & 676 & 469 & 787 & 787 & 4.469 & 1,45 \\
\hline Rescisão & 1.500 & 2.807 & 2.651 & - & - & - & 6.958 & 2,25 \\
\hline Consultoria & - & - & - & - & - & - & - & - \\
\hline FETHAB/GTA/FE & 7.686 & 6.062 & 4.998 & 4.438 & 2.077 & 835 & 26.095 & 8,44 \\
\hline Manutenção & 1.837 & 2.296 & 1.806 & 3.250 & 1.119 & 3.209 & 13.517 & 4,37 \\
\hline Rastreamento & 240 & 270 & - & - & - & - & 510 & 0,16 \\
\hline Sal & - & 24.000 & - & - & - & - & 24.000 & 7,76 \\
\hline Proteinado x 30 & 19.163 & 13.200 & 16.913 & - & 17.600 & 19.235 & 86.110 & 27,85 \\
\hline Combustível & 195 & - & 165 & 258 & 390 & 415 & 1.422 & 0,46 \\
\hline Remédio & - & 558 & 3.629 & 438 & - & 807 & 5.431 & 1,76 \\
\hline Vacina & - & - & 252 & - & - & 3.549 & 3.801 & 1,23 \\
\hline Mat. Construção & - & 3.795 & - & - & 1.557 & - & 5.352 & 1,73 \\
\hline Ref curral & - & 617 & - & 1.000 & 1.465 & 1.440 & 4.522 & 1,46 \\
\hline Roçada & - & 6.000 & 3.500 & 2.842 & - & - & 12.342 & 3,99 \\
\hline Arame & - & 470 & - & - & 400 & 2.500 & 3.370 & 1,09 \\
\hline Frete & - & - & - & - & - & - & - & - \\
\hline Frete ração e sal & 1.272 & - & 1.641 & 1.500 & - & 3.024 & 7.437 & 2,41 \\
\hline Diesel & - & - & 6.234 & - & 11.112 & 4.444 & 21.790 & 7,05 \\
\hline Outros gastos & - & 2.200 & 2.911 & 8.631 & 1.220 & 3.006 & 17.968 & 5,81 \\
\hline Contador & 152 & - & - & - & - & - & 152 & 0,05 \\
\hline Empreiteiro & - & - & 4.000 & 10.587 & 4.964 & 1.725 & 21.276 & 6,88 \\
\hline Lau & - & - & - & - & - & - & - & - \\
\hline Man. Veículo & - & - & - & - & - & 2.500 & 2.500 & 0,81 \\
\hline Total & 39.722 & 69.343 & 53.729 & 40.327 & 51.491 & 54.615 & 309.227 & 100 \\
\hline
\end{tabular}


Tabela 6 - Distribuição dos Custos de Produção Bovino no $2^{\circ}$ Semestre de 2008.

\begin{tabular}{|c|c|c|c|c|c|c|c|c|}
\hline Custos/Produção & & & Valore & Mensais & m (R\$) & & & \\
\hline Classificação & Jul & Agos & Set & Out & Nov & Dez & Total & $(\%)$ \\
\hline Energia & 352 & 372 & 287 & $\overline{451}$ & 681 & 353 & 2.496 & 0,64 \\
\hline Salários & 9.516 & 7.162 & 8.410 & 7.742 & 13.040 & 12.622 & 58.492 & 14,93 \\
\hline Encargos & 972 & 993 & 2.979 & 1.041 & 1.041 & 1.623 & 8.648 & 2,21 \\
\hline Rescisão & - & - & - & 3.811 & - & 1.469 & 5.280 & 1,35 \\
\hline Consultoria & 4.000 & 4.000 & 4.000 & 4.000 & 4.000 & 4.000 & 24.000 & 6,13 \\
\hline FETHAB/GTA/FE & 1.697 & 5.193 & 907 & 1.522 & 980 & 3.694 & 13.992 & 3,57 \\
\hline Manutenção & 3.298 & 1.035 & 2.958 & 4.880 & 469 & 1.261 & 13.901 & 3,55 \\
\hline Rastreamento & 700 & - & - & - & - & - & 700 & 0,18 \\
\hline Sal & 4.685 & 3.033 & 11.588 & - & 2.550 & - & 21.855 & 5,58 \\
\hline Proteinado x 30 & - & 49.167 & - & - & 14.000 & 15.750 & 78.917 & 20,14 \\
\hline Combústivel & 722 & 570 & 1.296 & 3.811 & - & 1.111 & 7.510 & 1,92 \\
\hline Remédio & 425 & & 322 & 549 & 175 & 1.997 & 3.468 & 0,89 \\
\hline Vacina & - & 858 & 285 & 233 & - & 5.556 & 6.932 & 1,77 \\
\hline Mat. Construções & - & 1.774 & 1.334 & 3.223 & - & 366 & 6.696 & 1,71 \\
\hline Ref. curral & - & - & - & - & - & - & - & - \\
\hline Roçada & - & - & - & - & - & - & - & - \\
\hline Arame & - & - & - & - & - & - & 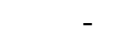 & 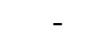 \\
\hline Frete & 91 & - & - & - & - & 6.493 & 6.584 & 1,68 \\
\hline Frete ração e sal & - & - & - & - & - & & - & - \\
\hline Diesel & 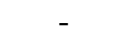 & - & 6.771 & 5.630 & 6.756 & 4.504 & 23.661 & 6,04 \\
\hline Outros gastos & 2.712 & 2.385 & 2.854 & 3.550 & 3.613 & 1.268 & 16.382 & 4,18 \\
\hline Contador & 979 & 166 & 166 & - & - & 734 & 2.045 & 0,52 \\
\hline Empreiteiro & 9.605 & 22.100 & 10.700 & 15.778 & 11.800 & 1.150 & 71.133 & 18,15 \\
\hline Lau & 9.112 & - & - & 2.265 & - & - & 11.377 & 2,90 \\
\hline Man. Veiculo & 3.038 & 905 & 1.014 & 1.730 & 694 & 383 & 7.764 & 1,98 \\
\hline Total & 51.905 & 99.710 & 55.870 & 60.216 & 59.799 & 64.333 & 391.833 & 100 \\
\hline
\end{tabular}

De acordo com a Tabela 7, os custos totais de produção do gado bovino no ano de 2008 na Fazenda Paraíso foram de R \$701.060,00. O maior custo de produção ficou com o item proteinado, salários/encargos e empreiteiro. Ocupando 23,54\%, 15,65\% e 13,18\% respectivamente do total dos custos de produção conforme análise vertical.

$\mathrm{Na}$ apuração dos custos de produção constatou que a empresa não calcula no seu custo a depreciação, exaustão e amortização. Conforme a "Lei 6.404/76 (Lei das Sociedades por Ações), a depreciação, amortização e exaustão devem ser contabilizadas para corresponder ao desgaste efetivo pelo uso ou perda da utilidade do bem ou direito, mesmo por ação da natureza ou obsolescência (CREPALDI 2005, p. 127)”. É bem verdade que de acordo com entrevista com o proprietário seria necessário, porém não o calcularam. 
Tabela 7 - Distribuição dos Custos de Produção Bovina no Ano de 2008.

\begin{tabular}{lrr}
\hline \multicolumn{1}{c}{ Classificação dos Custos de } & Totais em (R\$) & $\begin{array}{c}\text { Sobre o Total dos Custos } \\
(\mathbf{\%})\end{array}$ \\
\hline Energia & 4.557 & 0,65 \\
Salários & 96.637 & 13,78 \\
Encargos & 13.117 & 1,87 \\
Rescisão & 12.237 & 1,75 \\
Consultoria & 24.000 & 3,42 \\
FETHAB/GTA/FEFA & 40.087 & 5,72 \\
Manutenção & 27.417 & 3,91 \\
Rastreamento & 1.210 & 0,17 \\
Sal & 45.855 & 6,54 \\
Proteinado x 30 & 165.027 & 23,54 \\
Combustível & 8.932 & 1,27 \\
Remédio & 8.899 & 1,27 \\
Vacina & 10.733 & 1,53 \\
Mat. Construções & 12.048 & 1,72 \\
Ref. curral & 4.522 & 0,65 \\
Roçada & 12.342 & 1,76 \\
Arame & 3.370 & 0,48 \\
Frete & 6.584 & 0,94 \\
Frete ração e sal & 7.437 & 1,06 \\
Diesel & 45.451 & 6,48 \\
Outros gastos & 34.350 & 4,90 \\
Contador & 2.197 & 0,31 \\
Empreiteiro & 92.409 & 13,18 \\
Lau & 11.378 & 1,62 \\
Man. Veiculo & 10.264 & 1,46 \\
Total Geral & $\mathbf{7 0 1 . 0 6 0}$ & $\mathbf{1 0 0}$ \\
\hline & &
\end{tabular}

Para o cálculo da depreciação e exaustão o método utilizado foi o Linear. As pessoas mais indicadas para determinar as taxas de depreciação na atividade rural são agrônomos, veterinários, técnicos agropecuários ou os próprios agricultores que tem o conhecimento da vida útil ou a capacidade produtiva dos bens que compõem o Ativo Permanente da Empresa Rural (CREPALDI, 2005, p. 134). Neste estudo de caso, o tempo de vida útil de alguns bens foi estipulado mediante entrevista com o gerente e o proprietário da Fazenda.

Assim para questão de informação ao estudo e também aos demais. Foi elaborada a tabela de depreciação, exaustão e amortização de todos os bens cabíveis. Com base na Tabela 8, foram identificados todos os bens da fazenda Paraíso. De posse dessas informações foi efetuado o cálculo das depreciações, exaustão e amortização anual, totalizando valor de $\mathrm{R} \$$ 162.585,00. Desse total somente o valor de R \$667,00 da depreciação da casa sede/escritório, 
que não foi calculado como custo e sim como despesa do período. Reduzindo o custo de produção para $\mathrm{R} \$ 161.918,00$.

Tabela 8 - Depreciação das Instalações e Veículos, Exaustão de Pastagem e Amortização da Reforma de Pastagem no ano de 2008.

\begin{tabular}{lrrrr} 
& $\begin{array}{c}\text { Valor do bem } \\
(\mathbf{R} \mathbf{)})\end{array}$ & Vida Útil & Taxas $(\boldsymbol{\%})$ & Ao ano $(\mathbf{R} \mathbf{)})$ \\
\hline Motocicleta & 7.000 & 4 anos & 25 a.a & 1.750 \\
Veículo & 22.500 & 4 anos & 25 a.a & 5.625 \\
Trator de roda & 83.000 & 10 anos & 10 a.a & 8.300 \\
Plantadeira & 15.000 & 10 anos & 10 a.a & 1.500 \\
Grade de discos & 12.000 & 15 anos & 6,67 a.a & 800 \\
Adubadeira & 11.200 & 8 anos & 12,5 a.a & 1.400 \\
Roçadeira & 8.300 & 10 anos & 10 a.a & 830 \\
Curral & 300.000 & 20 anos & 5 a.a & 15.000 \\
Casa sede & 10.000 & 15 anos & 6,67 a.a & 667 \\
Instalações Operac. & 18.000 & 15 anos & 6,67 a.a & 1.201 \\
Barracão & 50.000 & 20 anos & 5 a.a & 2.500 \\
20 Cavalos Sela & 14.000 & 8 anos & 12,5 a.a & 1.750 \\
Pastagens & 1.540 .000 & 20 anos & 5 a.a & 77.000 \\
Cercas de arame & 270.000 & 10 anos & 10 a.a & 27.000 \\
40 Casas de cocho & 28.000 & 10 anos & 10 a.a & 2.800 \\
Reforma de Pasto & 101.271 & 7 anos & 14,28 a.a & 14.462 \\
Total & $\mathbf{2 . 4 9 0 . 2 7 1}$ & & & $\mathbf{1 6 2 . 5 8 5}$ \\
\hline
\end{tabular}

Em relação aos gastos com a reforma do pasto foi elaborada a tabela, que demonstra de forma discriminada cada item que foi necessário pra este evento.

Percebe-se na tabela 9, que o valor total do gasto foi de $\mathrm{R} \$ 101.271,00$. Na contabilidade da Fazenda este gasto foi contabilizado total como custo de produção no ano de 2008. Conforme explica Marion (2007, p. 76) gastos com melhorias no solo que propiciam incremento na capacidade produtiva, tais como desmatamento, corretivos, destocamento, nivelamento etc., devem ser amortizados num período não inferior a cinco anos e não maior que dez anos conforme determinação do Imposto de Renda e a Lei das Sociedades por Ações. Neste caso foi determinado pelo gerente da Fazenda um período de sete anos. Prazo que o bem pode ser usufruído.

Acompanhando todo o processo de produção na pecuária de corte na Fazenda Paraíso. Da compra a venda do rebanho. Os gastos ocorridos com o plantel e a receita obtida na comercialização. Necessário se faz apurar o resultado para apresentação do custo, volume e lucro da empresa na atividade operacional. 
Tabela 9 - Gastos com a Reforma de Setenta (70) Alqueires de Pastagens em 2008.

\begin{tabular}{|c|c|c|}
\hline Discriminação & Totais & Sobre o Total (\%) \\
\hline Gradiação & 23.800 & 24 \\
\hline Abubo & 42.750 & 42 \\
\hline Calcário & 27.121 & 26 \\
\hline Semente & 7.600 & 7,5 \\
\hline Total de gastos & 101.271 & 100 \\
\hline
\end{tabular}

Tabela 10 - Custo de Produção Média do Plantel em Janeiro de 2008.

\begin{tabular}{lr}
\hline \multicolumn{1}{c}{ Discriminação } & Valores (\$) \\
\hline Rebanho & 4.981 \\
Média de peso do rebanho (@) & 13 \\
Custo unitário do boi & 754 \\
Custo do rebanho total & 3.755 .674 \\
\hline
\end{tabular}

A partir do custo de aquisição conforme demonstrado na Tabela 10, foi identificado o custo unitário bovino. Totalizando um custo total de $\mathrm{R} \$$ 3.755.674. Em janeiro de 2008, o preço da arroba do boi gordo estava na média de $\mathrm{R} \$ 58,00$. Foi um período de transição para um aumento que perdurou durante todo o ano de 2008.

Tabela 11 - Custo de Produção Média do Plantel no Ano 2008.

\begin{tabular}{lc}
\hline \multicolumn{1}{c}{ Discriminação } & Valores (\$) \\
\hline Custo de produção total & 701.060 \\
Custo de produção unitário & 141 \\
Custo unitário do boi em 01/2008 & 754 \\
Custo unitário total & 895 \\
\hline
\end{tabular}

Após levantamento de todos os custos ocorridos durante o ano de 2008, conforme a Tabela 10, o custo unitário passou de $\mathrm{R} \$ 754,00$ para $\mathrm{R} \$ 895,00$. Sofrendo uma variação percentual de $15,5 \%$. Um aumento justo, uma vez que houve alta nos preços de todos os produtos que envolvem agropecuária. Impulsionado pelo bom momento no preço da arroba do boi gordo. Que passou o ano de 2008 na media de $\mathrm{R} \$ 70,00$ a arroba.

Conforme Tabela 12, foi apresentado comparativo a partir da aplicação dos custos de depreciação, exaustão e amortização. 
Tabela 12 - Custo de Produção Médio Incluso Depreciação, Exaustão e Amortização no ano de 2008.

\begin{tabular}{lc}
\hline \multicolumn{1}{c}{ Discriminação } & Valores (\$) \\
\hline Custo de produção & 701.060 \\
(-) Custo da reforma do pasto & 101.271 \\
(+) Custo de deprec. exaustão e amortiz. & $\mathbf{1 6 1 . 9 1 8}$ \\
Custo de produção total & 761.707 \\
Custo de produção unitário & 153 \\
Custo unitário do boi em 01/2008 & 754 \\
Custo unitário total & 907 \\
\hline
\end{tabular}

O custo de produção total passou de $\mathrm{R} \$ 701.060,00$ para $\mathrm{R} \$ 761.707,00$. Influenciando no custo unitário que passou de $\mathrm{R} \$ 895,00$ para $\mathrm{R} \$ 907,00$ sofrendo variação de 1,2\%. Alterando a apuração do resultado, ou seja, o lucro.

Através da tabela 13, foi apurado o resultado. O total de cabeças abatida foi de 4970. Totalizando receita bruta no valor de $\mathrm{R} \$ 5.928 .216,00$. O preço médio de venda da arroba do boi foi de $\mathrm{R} \$ 70,00$ totalizando valor unitário de $\mathrm{R} \$ 1.193,00$. Apuraram-se os gastos de produção totais e confrontou-se com a receita bruta. Apresentou-se lucro operacional em 2008 no valor de $\mathrm{R} \$ 1.481 .325,00$ obtendo retorno financeiro na faixa de $2,8 \%$ ao mês.

Tabela 13 - Resultado Apurado na Venda do Gado Bovino no Ano de 2008.

\begin{tabular}{lr}
\multicolumn{1}{c}{ Discriminação } & Valores (\$) \\
\hline Venda n $^{\text {o de cabeças }}$ & 4.970 \\
Média de Peso Rebanho @ & 17 \\
Preço Unitário de venda & 1.193 \\
Receita Bruta & 5.928 .216 \\
Custo de Produção & 699.511 \\
Custo do Rebanho & 3.747 .380 \\
Lucro Operacional antes deprec exaus amort e IR & 1.481 .325 \\
Lucro unitário & $\mathbf{2 9 8}$ \\
Receita Bruta & 5.928 .216 \\
Custo de Produção c/ deprec. exaus. e amort. & 760.025 \\
Custo do Rebanho & 3.747 .380 \\
Desp. Deprec & 667 \\
Lucro Operacional antes do IR & 1.420 .144 \\
Lucro unitário & $\mathbf{2 8 6}$ \\
\hline
\end{tabular}


Houve diferença dos custos de produção e no lucro operacional antes e após o cálculo de depreciação, exaustão e amortização. Realizou-se este cálculo apenas a crédito de acrescentar informações. Isso alterou o resultado, o lucro operacional antes do Imposto de Renda passou de R \$ 1.481.325,00 para R \$ 1.420.144,00. Diminuindo assim o lucro unitário em $\mathrm{R}$ \$ 12,00 sofrendo variação percentual de 1,1\%. Que passou de $\mathrm{R} \$ 298,00$ para $\mathrm{R} \$$ 286,00. Somente a título de comparação se a arroba do boi gordo permanecesse na média de 58,00. A empresa reduziria seu lucro totalmente, teria uma receita de $\mathrm{R} \$ 4.900 .420,00$. Admitindo que os custos de produção se mantivessem, o lucro operacional seria de $\mathrm{R} \$$ $453.529,00$, reduzindo em $\mathrm{R} \$ 1.000 .000,00$ praticamente. O retorno financeiro ficaria na faixa de $0,85 \%$ ao mês. Quitaria todos os gastos e estaria competindo com a poupança.

\section{CONSIDERAÇÕES FINAIS}

O objetivo deste estudo foi analisar os custos de produção da Fazenda Paraíso, que desenvolve atividade na pecuária de corte. $\mathrm{O}$ enfoque foi voltado para todos os detalhes que envolvem os gastos na produção bovina. A média de peso dos plantéis na aquisição foi de doze arrobas acima diminuindo assim o ciclo operacional para no máximo dois anos. Foram utilizadas informações científicas e econômicas no sentido de dar suporte ao estudo. Compreender e providenciar aos gestores ferramentas que são imprescindíveis na administração das propriedades rurais. Procurou associar Contabilidade de Custos à atividade operacional da empresa. Usufruindo de sistema que proporciona ao gestor informações sustentáveis. Que auxilia nas decisões, nas previsões e que pode contribuir com o aumento da produtividade, a minimização dos custos, na apuração do resultado e no desenvolvimento da empresa rural.

A abordagem da contabilidade de custos mostrou o grau de relevância de sua aplicação durante o estudo. Associada ao controle dos registros de toda movimentação na atividade operacional da Fazenda. Proporciona controle e segurança na decisão. Através desta ferramenta o empresário rural, os gestores podem visualizar sua atuação na atualidade e no futuro, definir metas, objetivos e estabelecer prioridades.

O aumento na arroba do boi gordo no ano de 2008 deixou os produtores rurais otimistas. Fortalecendo a classe que havia alguns anos sofrendo com quedas no preço da arroba do boi, ocasionando muitas vezes em prejuízos. Para sobreviver os produtores 
tentavam minimizar os custos. Foi esclarecido que a classe está atenta as modificações, que devem ocorrer no sentido de melhorar a qualidade do produto. O Brasil no cenário mundial é privilegiado, ocupa a posição de maior exportador de carne bovina e possui o maior rebanho comercial do mundo. Com uma capacidade produtiva que pode fortalecer ainda mais, dependendo na sua maioria de investimentos.

Na Fazenda Paraíso os gestores são muitos criteriosos quanto ao tratamento com os animais como: pastagens, suplementação mineral, sanidade, medidas preventivas de doenças, melhoramento genético, manejo etc. As instalações são adequadas à atividade operacional da empresa. O objetivo central é a engorda em períodos curto. O proprietário apresentou toda a estratégia no manejo dos animais. Estão focados no compromisso de administrar bem para conseguir o objetivo primordial da empresa, que é maximizar os lucros.

Conclui-se que após levantamento de todos os custos de produção, a Fazenda Paraíso conhece o seu custo de produção, apesar de não considerar alguns custos. A empresa no ano de 2008 foi surpreendida com aumento considerável no preço da arroba do boi maximizando os lucros, que há muitos anos não acontecia. Confirmando assim o objetivo geral do estudo, que era verificar se a empresa consegue retorno financeiro na venda do plantel. Na apuração do resultado no confronto da receita bruta e dos gastos de produção, percebe uma lucratividade bem maior do que a prevista pelo proprietário. Foi analisado o custo, volume e lucro ocorrido no ano de 2008. A empresa mostrou que está ligada na competitividade e nas mudanças de mercado. Aplica um processo rigoroso na produção capaz de garantir qualidade ao resultado.

Enfatiza-se que o conteúdo ora apresentado é objeto de transição, pois o preço dos produtos é determinado pelo mercado e não por quem os produz, os temas tratados não pretendem concluir estando aberto a novos estudos.

\section{REFERÊNCIAS}

A Pecuária e Sua Importância no Brasil. Disponível em: $<$ http://www.fontesosaber.com/geografia/a-pecuaria-e-sua-importanc-no-brasilhtml >. Acesso em $03 / 11 / 08$.

ARAÚJO, Massilon J. Araújo. Fundamentos de Agronegócios. - 2. Ed. - 3. Reimpr. - São Paulo : Atlas, 2008.

BATALHA, Mário Otávio. Gestão Agroindustrial: GEPAI: Grupo de estudos e pesquisas agroindustriais. 3. ed. - São Paulo: Atlas, 2007. 
BONFIM, Suzi-Redação/Seder-MT: disponível em HTTP://www.secom.mt.gov.br/conteudo2.phd?sid=25\&cid=3627\&pa.. Acesso em 03/11/2008.

BOTELHO, Gilmara. PIB Agropecuário Desacelera no Terceiro Trimestre do Ano. 11/12/2008, Gazeta Mercantil/Caderno B - Pág. 11. Disponível em:

http://indexet.gazetamercantil.com.br/arquivo/2008/12/11/100/PIB-agropecuario-desacelerano-terceiro-trimestre-do-ano.html. Acesso em 10/04/2009.

CALLADO, Antônio André Cunha (organizador). Agronegócio. - 1. Ed.-2. reimpressão São Paulo : Atlas, 2006.

COELHO, Felipe Soares. et al. Levantamento e Análise dos Custos Médios de Produção de Bovinos de Corte no Município de Curvelo, Minas Gerais. SOBER Sociedade Brasileira de Economia, Administração e Sociologia Rural, 2006.

CREPALDI, Silvio Aparecido. Contabilidade Gerencial: teoria e prática. - 3. ed. - São Paulo: Atlas, 2004.

CREPALDI, Silvio Aparecido. Contabilidade Rural: uma abordagem decisorial. - 3. ed. revista, atualizada e ampliada - São Paulo: Atlas, 2005.

FERREIRA, Aurélio Buarque de Holanda; Miniaurélio: o dicionário da língua portuguesa; coordenação de edição Margarida dos Anjos, Marina Baird Ferreira - 6. ed. rev. atual Curitiba : Positivo, 2006.

GIL, Antonio Carlos. Como Elaborar Projetos de Pesquisa. $4^{\circ}$ ed. - 10. reimp. - São Paulo: Atlas, 2007.

HARRIS Frederick H deb., Mcguigan James R., Economia de Empresas: aplicações, estrategia e taticas/ R. Charles Moyer, Harris; tradução Roberto Galman; revisão tecnica Gilberto Miyamoto - Sao Paulo: Pioneira Thomson Learning, 2004.

IBGE - Instituto Brasileiro de Geografia e Estatística, Diretoria de Pesquisas, Coordenação de Agropecuária, Pesquisa da Pecuária Municipal 2007. Disponível em:

<http://www.ibge.gov.br>. Acesso em 15/01/2009.

IBGE - Instituto Brasileiro de Geografia e Estatística. Censo Agropecuário 2006. Disponível em: 〈http://www.ibge.gov.br/home/estatistica /economia/agropecuaria/censoagro/2006>.

Acesso em 03.11.2008.

Informação e Cultura. Carne Bovina no Brasil, 2006. Disponível em: $<$ http://www.correiogourmand.com.br/info_glossario_produtos_alimentos_...>. Acesso em 03/11/08.

LIMA, Victor Muiños Barroso, et al. 2007. SISBOV: Entendendo o Passado, Planejando o Futuro. XIV Congresso da SOBER. Disponível em:

<http://www.sober.org.br/palestra/6/495.pdf>. Acesso em 09/04/08.

LUCHIARI FILHO, Albino. Produção de Carne Bovina no Brasil, Qualidade, Quantidade ou Ambas?II SIMBOI-Simpósio sobre Desafios e Novas Tecnologias na Bovinocultura de 
Corte, 29 a 30.04.2006, Brasilia-DF. Disponível em: 〈www.upis.br/simboi/anais.asp> . Acesso em 12/10/08.

MARION, José Carlos. Contabilidade Básica. $7^{\circ}$ ed. São Paulo: Atlas, 2004.

MARION, José Carlos. Contabilidade e Controladoria em Agrobusiness. São Paulo: Atlas, 1996.

MARION, José Carlos. Contabilidade Rural: Contabilidade Agrícola, Contabilidade da Pecuária, Imposto de Renda Pessoa Jurídica. - 8. ed. - 3. Reimpr. - São Paulo: Atlas, 2007.

MARION, José Carlos. SEGATTI, Sonia Maria. Contabilidade da Pecuária. - 8. Ed. - São Paulo : Atlas, 2007.

MARTINS, Eliseu,1945 - Contabilidade de Custos - 9. ed. - 6. Reimpr. São Paulo : Atlas, 2006.

MEGLIORINI, Evandir. Custos: análise e gestão. - 2. Ed. - São Paulo : Pearson Prentice Hall, 2007.

MEISTER, Luiz Carlos. et al. Federação da Agricultura e Pecuária do Estado de Mato Grosso (FAMATO) e Fundo de Apoio a Bovinocultura de Corte (FABOV). Diagnóstico da Cadeia Produtiva Agroindustrial da Bovinocultura de Corte do Estado de Mato Grosso.

Cuiabá, outubro de 2007.

MORENO, Gislaine. HIGA Cristina Souza (orgs.): colaboradora Gilda Tomasini Maitelli Geografia de Mato Grosso: Território, sociedade, ambiente / Tereza. - Cuiabá: Entrelinhas, 2005.

PADOVEZE, Clóvis Luís. Contabilidade Gerencial: um enfoque em sistema de informação contábil. - 4. ed. - São Paulo: Atlas, 2004.

Produção da Pecuária Municipal 2006v.34-Brasil. Disponível em:

<http://www.ibge.gov.br/home/presidencia/noticias/noticia_visualiza.php?id_n....> Acesso em $17 / 11 / 08$.

RIBEIRO, Magno Alves. Manual para elaboração e apresentação de monografias: com noções introdutórias de metodologia. Tangará da Serra (MT). Unemat, 2006.

SILVA, Jovam Vilela da. Um Breve Relato da Formação Populacional (século XVII ao XX). - Cuiabá: KCM, 2006.

VASCONCELLOS, Marco Antonio Sandoval, OLIVEIRA, Roberto Guena de. -2 ed. - São Paulo : Atlas, 2000.

VICECONTI, Paulo Eduardo Vilchez, NEVES Silverio das - Contabilidade de Custos. 8.ed. rev.e ampl.-São Paulo : Frase Editora, 2008. 
Gestão de custos aplicada à bovinocultura de corte: o caso da fazenda Paraíso em Juina-MT

Rosangela Nunes da Silva de Souza

Laércio Juarez Melz 